\title{
Comparative Efficacy, Selection of Effective Partners, and Application Time of Strobilurin Fungicides for Control of Cercospora Leaf Spot of Sugar Beet
}

\author{
D. A. Karadimos, Hellenic Sugar Industry S.A., Plant Protection Department, Sugar Factory of Larissa, 41110, \\ Larissa, Greece; and G. S. Karaoglanidis, Hellenic Sugar Industry S.A., Plant Protection Department, Sugar Factory \\ of Platy, 59032, Platy Imathias, Greece
}

\begin{abstract}
Karadimos, D. A., and Karaoglanidis, G. S. 2006. Comparative efficacy, selection of effective partners, and application time of strobilurin fungicides for control of Cercospora leaf spot of sugar beet. Plant Dis. 90:820-825.

In this study, we attempt to optimize the use of strobilurin fungicides by testing the efficacy of azoxystrobin, kresoxim-methyl, pyraclostrobin, and trifloxystrobin under field conditions, by testing for the most efficient partners in fungicide mixtures, and by testing control efficacy of strobilurin fungicides applied at several application times to determine the better options for disease management. Results showed that trifloxystrobin was the most efficient strobilurin fungicide, followed by pyraclostrobin. Azoxystrobin provided a modest to poor control efficacy, whereas kresoxim-methyl provided only poor disease control efficacy. Mixtures of azoxystrobin and trifloxystrobin with either chlorothalonil or maneb and difenoconazole or flutriafol were tested for their efficacy in controlling the disease. The results showed that the azoxystrobincontaining mixtures provided significantly better control compared with that obtained by single applications of each mixture component. The mixtures of trifloxystrobin with maneb or with difenoconazole or flutriafol provided control efficacy similar to that obtained by single applications of trifloxystrobin, whereas the mixture of trifloxystrobin and chlorothalonil provided significantly lower control efficacy compared with the other trifloxystrobin-containing mixtures tested. For both strobilurin fungicides tested, the calculated ratio between the observed and the expected control efficacy ranged around the value of 1 , suggesting additive interactions between the mixtures' components. To determine the most appropriate time for strobilurin fungicides application, trifloxystrobin was applied as the first two, the middle two, or the final two consecutive treatments of six fungicide applications. The remaining fungicide treatments in the spray schedules were carried out by applying the systemic fungicide difenoconazole. Results showed that a higher control efficacy was obtained when trifloxystrobin was applied in either of the earlier applications.
\end{abstract}

Additional keywords: Cercospora beticola

Cercospora leaf spot, caused by Cercospora beticola, is the most destructive foliar disease of sugar beet worldwide, particularly in warm and humid regions such as parts of the Mediterranean basin $(7,23)$. Severe epidemics of the disease, in the absence of control measures, may cause yield losses ranging from 25 to $50 \%$ $(7,22)$. Despite the availability of sugar beet cultivars possessing moderate to high genetic disease resistance, successful control of the disease requires the use of fungicides $(23,24)$. Fungicides of several classes, such as the dithiocarbamates, fentin derivatives, benzimidazoles, and sterol demethylation inhibitors (DMIs), are available for use against the disease (19). However, development of resistance to

Corresponding author: G. S. Karaoglanidis E-mail: gkaro@agro.auth.gr

Accepted for publication 6 February 2006

DOI: 10.1094/PD-90-0820

(C) 2006 The American Phytopathological Society benzimidazoles, fentin derivatives, and DMIs, in both Greece and many other countries worldwide, has become a limitation to the sustained control of the disease by restricting the initial utility of these fungicides $(12,15)$.

Strobilurin fungicides constitute a relatively new fungicide class that has been developed from natural fungicidal derivatives such as strobilurin A, oudemansin A, and myxothiazol A (5). This fungicide class possesses a new mechanism of action consisting of inhibition of mitochondrial respiration by binding at the $\mathrm{Q}_{0}$ site of cytochrome $b$. Inhibition of mitochondrial respiration is achieved by blocking the electron transport between cytochrome $b$ and cytochrome $c_{1}$ which, in consequence, leads to a disruption of the energy cycle $(3,5)$. This fungicide class possesses an extremely broad spectrum of activity, including Ascomycetes, Deuteromycetes, Basidiomycetes, and Oomycetes $(1,18,26,28)$. Among the several pathogens that are efficiently controlled by strobilurin fungicides, $C$. beticola also is included, as has been shown by recent studies under both controlled environmental conditions $(2,13)$ and field conditions (16).

The current study was conducted to optimize the use of strobilurin fungicides against Cercospora leaf spot of sugar beet and specifically to (i) compare the efficacy of four strobilurin fungicides, azoxystrobin, trifloxystrobin, pyraclostrobin, and kresoxim-methyl, against the disease under field conditions and to determine the most effective doses; (ii) test the efficacy of mixtures of two strobilurin fungicides, azoxystrobin and trifloxystrobin, with other protective or systemic fungicides in order to select the most efficient fungicide partners; and (iii) determine the most effective application time for strobilurin fungicides.

\section{MATERIALS AND METHODS}

Cultural practices. The experiments were conducted during a 4-year period from 2002 to 2005 in the Larissa area, Thessaly, Greece. Different but adjacent fields were selected each year for the experiments. In this area, Cercospora leaf spot is the most important foliar disease of sugar beet due to the relatively warm and humid weather conditions prevailing during the summer. Usually, five to six fungicide spray applications per growing season are required for satisfactory disease control. The selected fields previously were cropped to cotton and, before sowing, received a fertilization of $20 \mathrm{~N}-8 \mathrm{P}-10 \mathrm{~K}$ at $700 \mathrm{~kg} / \mathrm{ha}$ during each of the 4 years of the study.

The sugar beet cultivar selected for the experiment was Rival, a cultivar susceptible to Cercospora leaf spot. Field plots consisted of six $8-\mathrm{m}$ rows spaced $50 \mathrm{~cm}$ apart and arranged in a completely randomized block design with four replicates per treatment. Plants were seeded with a commercial planter on 18 March 2002, 27 March 2003, 20 March 2004, and 23 March 2005. Field plots were treated with recommended herbicides and insecticides as needed. During the entire growing season, plants were sprinkler irrigated five to six times, receiving, on average, 40 to 50 $\mathrm{mm}$ of water per irrigation.

Fungicides. Fungicides used in the study were the commercial formulations of trifloxystrobin (Flint 50 WG; Bayer Cropscience Hellas), pyraclostrobin (F-500 25 EC; BASF Hellas), kresoxim-methyl (Strobby 50WG; BASF Hellas), azox- 
ystrobin (Ortiva 25 SC; Syngenta Hellas), difenoconazole (Score 25 EC; Syngenta Hellas), flutriafol (Impact 12.5 SC; Cheminova Denmark), chlorothalonil (Daconil 75WP; BASF Hellas), and maneb (Dithane M-22, $80 \mathrm{WP}$; BASF Hellas).

Fungicides were applied preventively, using an AZO precision sprayer, at a volume of 0.4 liter/plot and pressure of $4 \mathrm{~atm}$ (405 kPa). Spray applications were initiated before the appearance of any disease symptom on the plants, at the "closing" of the rows, and were repeated at intervals of 15 to 20 days, as recommended in the practice. In total, six spray applications per treatment were carried out.

Strobilurin fungicide efficacy. The efficacy of four strobilurin fungicides, azoxystrobin, kresoxim-methyl, pyraclostrobin, and trifloxystrobin, applied at three different doses of 100, 150, and $200 \mathrm{~g}$ a.i. ha ${ }^{-1}$, was tested in a 2-year experiment carried out in 2002 and 2003. Difenoconazole applied at $150 \mathrm{~g}$ a.i. $\mathrm{ha}^{-1}$ and chlorothalonil applied at $1.500 \mathrm{~g}$ a.i. $\mathrm{ha}^{-1}$ were included in the experimental design as standard fungicide treatments.

Efficacy of fungicide mixtures. The efficacy of various fungicide mixtures, including two strobilurin fungicides, azoxystrobin and trifloxystrobin, with two protective and two systemic fungicides, was evaluated in a 2-year field experiment carried out during 2003 and 2004. Azoxystrobin and trifloxystrobin were applied in the mixtures at the dose of $150 \mathrm{~g}$ a.i. $\mathrm{ha}^{-1}$. Chlorothalonil and maneb applied in the mixtures at 750 and $2,000 \mathrm{~g}$ a.i. $\mathrm{ha}^{-1}$, respectively, were the protectant fungicides included in the study, whereas difenoconazole and flutriafol, applied in the mixtures at 75 and $50 \mathrm{~g}$ a.i. $\mathrm{ha}^{-1}$, respectively, were the systemic fungicides included in the study. Single applications of all these fungicides, at the same doses, were included in the experimental design to allow evaluation of synergistic, antagonistic, or additive interactions of fungicide partners in the mixtures tested.

To estimate the extent of interactions among the two strobilurin fungicides tested and the partner fungicides, the method suggested by Gisi (8) was used. In more detail, the expected efficacy of each fungicide mixture $\left(\% C_{\exp }\right)$ was estimated by the formula:

$$
\% C_{\text {exp }}=A+B-(A B / 100)
$$

where $A$ and $B$ are the control levels given by the single fungicides. If the ratio between the experimentally observed efficacy of the mixture $\left(C_{\text {obs }}\right)$ and the expected efficacy of the mixture $\left(C_{\exp }\right)$ was lower than 0.5 , antagonistic interactions were considered to be present in the mixture; if the ratio was ranged between 0.5 and 1.5, the interaction was considered to be additive; and if the ratio was higher than 1.5, the interaction was considered to be synergistic.
Time of strobilurin fungicides application. The effect of the timing of strobilurin fungicides application was determined in a 2-year field experiment carried out during 2004 and 2005. The strobilurin fungicide selected for the experiment was trifloxystrobin applied at $150 \mathrm{~g}$ a.i. $\mathrm{ha}^{-1}$. The fungicide was used at blocks of two successive applications in the spray schedule. It was applied in the first two applications (first and second), the two intermediate spray applications (third and fourth), or the last two spray applications (fifth and sixth). The remaining spray applications in each treatment were carried out with the systemic fungicide difenoconazole, also applied at $150 \mathrm{~g}$ a.i. $\mathrm{ha}^{-1}$. The complete spray application schedule is shown in Table 1.

Disease assessment. Disease development was assessed visually using the 12degree rating scale of Horsfall and Barrat (11). Assessments of the disease began just after the appearance of symptoms and were repeated at 10- to 15-day intervals until the end of the experiment. Area under disease progress curve (AUDPC) was calculated for the assessment period as follows (24):

$$
\mathrm{AUDPC}=\sum_{i=1}^{n}\left[\left(Y_{i+1}+Y_{i}\right) / 2\right]\left(t_{i+1}-t_{i}\right)
$$

where $Y_{i}=$ disease severity at the $i$ th observation, $t_{i}=$ time (days) at the $i$ th observation, and $n=$ total number of observations.

Yield parameters. Yield measurement was carried out in the experiment conducted to compare the efficacy of the four strobilurin fungicides applied in three different doses. Plots were hand-harvested on 28 September 2002 and 6 October 2003. The middle two rows of each plot were harvested and weighed to estimate root yield. Then, 15 randomly selected roots from each plot were transferred to the Chemistry Laboratory of the Larissa Sugar Factory, Hellenic Sugar Industry S.A., Larissa, Greece, for the measurement of sucrose concentration. The evaluated parameters were root weight, sucrose concentration percentage, and sucrose yield per hectare.

Data analysis. Data on foliage damage, AUDPC values, control efficacy values, root weight, sucrose concentration, and sucrose yield were subjected in an analysis of variance (ANOVA) and compared using the Fischer's least significant difference (LSD) procedure at $P=0.05$. Percentage values were transformed to arcsine $\sqrt{ } \%$ for statistical analysis. The statistical analysis was supported by the Mstat-C statistical program (version 2.10; Michigan State University, East Lansing).

\section{RESULTS}

Control efficacy of strobilurin fungicides. During both years of the study, a disease epidemic was initiated naturally. More frequent rains that prevailed during the summer of 2002 led to higher disease severity compared with that observed during 2003. In 2002, the first disease symptoms were observed 120 days after planting and, within 50 days, plant foliage was almost completely destroyed in the untreated control plots (Fig. 1); whereas, in 2003, the first disease symptoms were observed 150 days after planting and the foliage was completely destroyed in the untreated control plots about 190 days after planting (Fig. 1). In the early stages of disease development, foliage damage in plots treated with the several fungicides tested was similar $(P>0.05)$. However, progressively, differences in disease severity in fungicide-treated plots were obvious (Fig. 1). The efficacy of each fungicide treatment was determined based on AUDPC values (Table 2). The most effective fungicide was trifloxystrobin which, in all the three doses tested, provided control efficacy higher than $80 \%$ during both years of the study, followed by pyraclostrobin, which also provided very high control efficacy in all three doses tested. The remaining two strobilurin fungicides were significantly less effective than trifloxystrobin and pyraclostrobin. Applications of azoxystrobin and kresoxim-methyl at the highest dose tested $\left(200 \mathrm{~g}\right.$ a.i. ha $\left.^{-1}\right)$ was less effective $(P<0.05)$ than applications of pyraclostrobin or trifloxystrobin at the lowest dose tested $\left(100 \mathrm{~g}\right.$ a.i. $\left.\mathrm{ha}^{-1}\right)$. Difenoconazole, a fungicide of known systemic activity, applied at $150 \mathrm{~g}$ a.i. ha ${ }^{-1}$ provided a control efficacy lower $(P<$ $0.05)$ than that of pyraclostrobin or trifloxystrobin applied at $200 \mathrm{~g}$ a.i. $\mathrm{ha}^{-1}$ during 2002 and not significantly different $(P>$ 0.05 ) from that of the two strobilurin fungicides during 2003. Chlorothalonil, a

Table 1. Experimental design of a field experiment conducted during 2004 and 2005 to study the effect of application time of trifloxystrobin on the control of Cercospora leaf spot on sugar beet

\begin{tabular}{lllllll}
\hline & \multicolumn{7}{c}{ Number of spray application } \\
\cline { 2 - 7 } Treatment & 1st & 2nd & 3rd & 4th & 5th & 6th \\
\hline 1 & Tr & Tr & Tr & Tr & Tr & Tr \\
2 & Dif & Dif & Dif & Dif & Dif & Dif \\
3 & Tr & Tr & Dif & Dif & Dif & Dif \\
4 & Dif & Dif & Tr & Tr & Dif & Dif \\
5 & Dif & Dif & Dif & Dif & Tr & Tr \\
6 & UC & UC & UC & UC & UC & UC \\
\hline
\end{tabular}

${ }^{\mathrm{z}}$ Dif $=$ difenoconazole at $150 \mathrm{~g}$ a.i. $\mathrm{ha}^{-1}, \mathrm{Tr}=$ trifloxystrobin at $150 \mathrm{~g}$ a.i. $\mathrm{ha}^{-1}$, and $\mathrm{UC}=$ untreated control. 
fungicide of known protective activity against the disease, failed to adequately protect the crop under the extremely favorable conditions of 2002 but provided a modest control of the disease during 2003, which was not significantly different $(P>$
0.05) from that provided by azoxystrobin or pyraclostrobin applied at $200 \mathrm{~g}$ a.i. $\mathrm{ha}^{-1}$. Measurements of yield components showed that sucrose yield in all the fungicide-treated plots was higher $(P<0.05)$ compared with the control treatment dur-

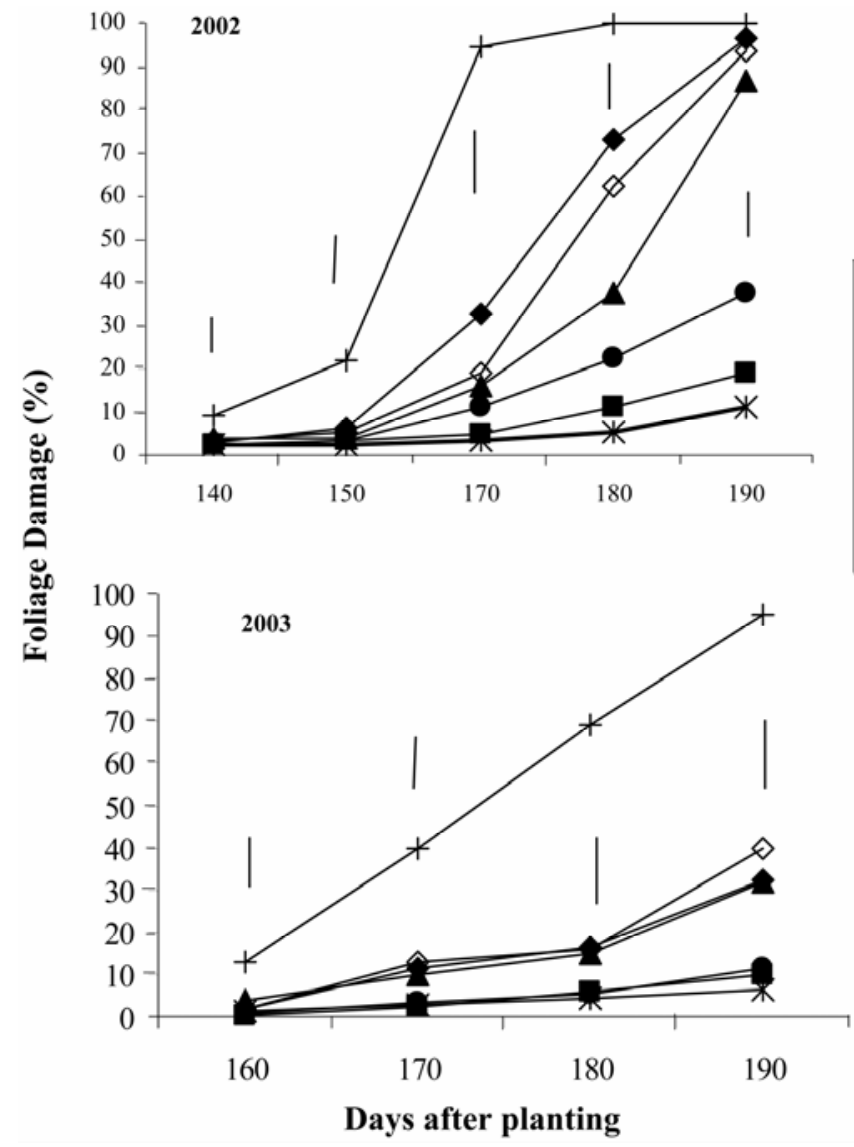

Fig. 1. Disease severity, in terms of foliar damage (\%), of Cercospora leaf spot of sugar beet in field plots treated with several fungicides during a 2-year period, 2002 to 2003. Chlorothalonil, difenoconazole, azoxystrobin, kresoxim-methyl, pyraclostrobin, and trifloxystrobin were applied at the rate of $1.500,150,200,200$, and $200 \mathrm{~g}$ a.i. ha ${ }^{-1}$, respectively. Vertical lines represent the least significant differences $(P<0.05)$ for each assessment date.

ing both years of the study. Both pyraclostrobin and trifloxystrobin applied at $200 \mathrm{~g}$ a.i. ha $^{-1}$ provided significantly higher $(P<$ $0.05)$ sucrose yield than the remaining two strobilurin fungicides tested (Table 2).

Control efficacy of fungicide mixtures. All the fungicide mixture partners used in the experiments were applied at half of the commercially recommended dose. During both years of the study, single applications of the mixture components failed to protect the crop satisfactorily, with the exception of trifloxystrobin (Table 3). Even when applied alone at the dose of $150 \mu \mathrm{g} \mathrm{ml}^{-1}$, trifloxystrobin provided control of 93.8 and $89.4 \%$ during 2003 and 2004, respectively. The mixtures of azoxystrobin with either maneb or chlorothalonil and flutriafol or difenoconazole provided significantly higher $(P<0.05)$ control efficacy compared with the efficacy obtained by single applications of each mixture component during both years of the study. The observed control efficacy of azoxystrobin mixtures was almost identical to the expected control efficacy, with ratio values ranging from 1.00 to 1.03 during 2003 and 1.09 to 1.13 during 2004 (Table 3). Such data indicate an additive interaction between the fungicide mixture components. During both years of the study, disease severity, in terms of AUDPC values, in plots treated with the mixtures of azoxystrobin and either difenoconazole or flutriafol was similar $(P>0.05)$, whereas disease severity in plots treated with the mixture of azoxystrobin and difenoconazole was significantly lower $(P<0.05)$ compared with the disease severity in plots treated with the mixtures of azoxystrobin with either chlorothalonil or maneb.

Regarding the control efficacy obtained by applications of trifloxystrobin mixtures with either maneb or chlorothalonil and

Table 2. Area under the disease progress curve (AUDPC) of Cercospora leaf spot on sugar beet, control efficacy (\%) and yield parameters in plots treated with several strobilurin fungicides in 2002 and $2003^{\mathrm{y}}$

\begin{tabular}{|c|c|c|c|c|c|c|c|c|c|c|c|}
\hline \multirow[b]{3}{*}{ Treatment } & \multirow[b]{3}{*}{ Appl. } & \multicolumn{10}{|c|}{ Year $^{\mathrm{z}}$} \\
\hline & & \multicolumn{5}{|c|}{2002} & \multicolumn{5}{|c|}{2003} \\
\hline & & AUDPC & Cont. & Root & Sugar & Sucrose & AUDPC & Cont. & Root & Sugar & Sucrose \\
\hline Chlorothalonil & 1.500 & $2.191 \mathrm{~b}$ & $38.3 \mathrm{j}$ & $119.7 \mathrm{bcd}$ & $13.30 \mathrm{~g}$ & $15.9 \mathrm{ef}$ & $564 \mathrm{def}$ & $72.0 \mathrm{e}$ & $94.4 \mathrm{~d}$ & $15.22 \mathrm{bcd}$ & $14.3 \mathrm{~g}$ \\
\hline Difenoconazole & 150 & $758 \mathrm{fg}$ & $78.7 \mathrm{~d}$ & $126.2 \mathrm{ab}$ & $14.23 \mathrm{abcd}$ & $17.9 \mathrm{ab}$ & $189 \mathrm{gh}$ & $90.7 \mathrm{~b}$ & $96.3 \mathrm{~d}$ & $15.33 \mathrm{bcd}$ & $14.7 \mathrm{efg}$ \\
\hline Azoxystrobin & 100 & $1.847 \mathrm{c}$ & $48.0 \mathrm{~h}$ & $121.3 \mathrm{abcd}$ & 13.77 ef & $16.7 \mathrm{de}$ & $741 \mathrm{bcd}$ & $63.2 \mathrm{~h}$ & $113.0 \mathrm{ab}$ & $15.16 \mathrm{~d}$ & $17.1 \mathrm{~b}$ \\
\hline Azoxystrobin & 150 & $1.777 \mathrm{~cd}$ & $50.0 \mathrm{~g}$ & $122.2 \mathrm{abc}$ & $13.82 \mathrm{ef}$ & $16.8 \mathrm{~cd}$ & $686 \mathrm{cde}$ & $66.0 \mathrm{~g}$ & $94.7 \mathrm{~d}$ & $15.35 \mathrm{bcd}$ & $14.5 \mathrm{fg}$ \\
\hline Azoxystrobin & 200 & $1.356 \mathrm{e}$ & $61.9 \mathrm{f}$ & $119.7 \mathrm{bcd}$ & $13.77 \mathrm{cdef}$ & $16.4 \mathrm{def}$ & $537 \mathrm{defg}$ & $73.4 \mathrm{e}$ & $97.5 \mathrm{~d}$ & $15.29 \mathrm{~cd}$ & $14.9 \mathrm{def}$ \\
\hline Kresoxim-methyl & 100 & $2.217 \mathrm{~b}$ & $37.6 \mathrm{j}$ & $116.8 \mathrm{~cd}$ & $13.49 \mathrm{fg}$ & $15.7 \mathrm{f}$ & $1.051 \mathrm{~b}$ & $47.8 \mathrm{j}$ & $97.0 \mathrm{~d}$ & $15.73 \mathrm{abc}$ & $15.2 \mathrm{de}$ \\
\hline Kresoxim-methyl & 150 & $2.132 \mathrm{~b}$ & $40.0 \mathrm{i}$ & $119.2 \mathrm{bcd}$ & $13.65 \mathrm{fg}$ & $16.2 \mathrm{def}$ & $911 \mathrm{bc}$ & $54.8 \mathrm{i}$ & $109.3 \mathrm{abc}$ & $14.88 \mathrm{~d}$ & $16.2 \mathrm{c}$ \\
\hline Kresoxim-methyl & 200 & $1.808 \mathrm{de}$ & $49.1 \mathrm{gh}$ & $123.0 \mathrm{abc}$ & $13.88 \mathrm{def}$ & $17.0 \mathrm{~cd}$ & 629 cde & $68.8 \mathrm{f}$ & $106.0 \mathrm{c}$ & $15.35 \mathrm{bcd}$ & $16.2 \mathrm{c}$ \\
\hline Trifloxystrobin & 100 & $676 \mathrm{fg}$ & $81.0 \mathrm{~cd}$ & $128.4 \mathrm{a}$ & $14.51 \mathrm{a}$ & $18.6 \mathrm{a}$ & $376 \mathrm{efgh}$ & $81.4 \mathrm{~d}$ & $110.1 \mathrm{abc}$ & $15.75 \mathrm{ab}$ & $17.3 \mathrm{~b}$ \\
\hline Trifloxystrobin & 150 & $311 \mathrm{i}$ & $91.3 \mathrm{ab}$ & $127.6 \mathrm{a}$ & $14.46 \mathrm{a}$ & $18.4 \mathrm{a}$ & $193 \mathrm{gh}$ & $90.5 \mathrm{bc}$ & $108.1 \mathrm{bc}$ & $15.79 \mathrm{ab}$ & $17.0 \mathrm{~b}$ \\
\hline Trifloxystrobin & 200 & $226 \mathrm{i}$ & $93.7 \mathrm{a}$ & $127.6 \mathrm{a}$ & $14.56 \mathrm{a}$ & $18.5 \mathrm{a}$ & $134 \mathrm{~h}$ & $93.4 \mathrm{a}$ & $113.1 \mathrm{a}$ & $15.98 \mathrm{a}$ & $18.0 \mathrm{a}$ \\
\hline Pyraclostrobin & 100 & $937 \mathrm{f}$ & $73.7 \mathrm{e}$ & $122.5 \mathrm{abc}$ & $14.26 \mathrm{abc}$ & $17.4 \mathrm{bc}$ & $381 \mathrm{efgh}$ & $81.1 \mathrm{~d}$ & $111.7 \mathrm{ab}$ & $15.29 \mathrm{bcd}$ & $17.0 \mathrm{~b}$ \\
\hline Pyraclostrobin & 150 & $617 \mathrm{gh}$ & $82.7 \mathrm{c}$ & $125.3 \mathrm{ab}$ & 14.09 bcde & $17.6 \mathrm{bc}$ & $230 \mathrm{fgh}$ & $88.6 \mathrm{c}$ & $96.5 \mathrm{~d}$ & $16.05 \mathrm{a}$ & $15.4 \mathrm{~d}$ \\
\hline Pyraclostrobin & 200 & $381 \mathrm{hi}$ & $89.3 \mathrm{~b}$ & $125.5 \mathrm{ab}$ & $14.37 \mathrm{ab}$ & $18.0 \mathrm{ab}$ & $172 \mathrm{~h}$ & $91.5 \mathrm{ab}$ & $109.9 \mathrm{abc}$ & $15.93 \mathrm{a}$ & $17.5 \mathrm{ab}$ \\
\hline Control & $\ldots$ & $3.550 \mathrm{a}$ & $\ldots$ & $114.5 \mathrm{~d}$ & $12.56 \mathrm{~h}$ & $14.3 \mathrm{~g}$ & $2.012 \mathrm{a}$ & $\ldots$ & $93.3 \mathrm{~d}$ & $14.27 \mathrm{e}$ & $13.3 \mathrm{~h}$ \\
\hline
\end{tabular}

y AUDPC values were calculated according to Wolf and Verreet (24). Percentage control values were calculated as 100 - incidence (treated)/incidence (untreated). Percentage values were transformed to arcsine $\sqrt{ } \%$ for statistical analysis. Means followed by different letters in the column are significantly different according to Fischer's least significant difference test at $P=0.05$.

${ }^{\mathrm{z}}$ Appl. $=$ application dose, g a.i. ha ${ }^{-1} ;$ Cont. $=$ control $(\%) ;$ Root $=$ root yield, ton ha ${ }^{-1} ;$ Sugar $=$ sugar content $(\%) ;$ Sucrose $=$ sucrose yield, ton ha ${ }^{-1}$. 
flutriafol or difenoconazole, the results showed that, in most combinations tested, it was similar to that obtained by single applications of trifloxystrobin alone during both years of the study. As previously mentioned, trifloxystrobin applied alone at a rate of $150 \mu \mathrm{g} \mathrm{ml}^{-1}$ provided excellent control of the disease. During both years of the study, the mixtures of trifloxystrobin with the protective fungicide maneb or the DMI fungicides difenoconazole or flutriafol provided control efficacy values higher than $90 \%$ (Table 3). The observed control efficacy obtained by these trifloxystrobin mixtures was identical to the expected control efficacy, with ratio values ranging from 0.97 to 0.99 during 2003 and 1.00 to 1.03 during 2004 (Table 3 ), suggesting an additive interaction between the fungicide mixture components. In contrast, control efficacy obtained by the mixture of trifloxystrobin with chlorothalonil was significantly lower $(P<0.05)$ than the remaining mixtures of trifloxystrobin, with values of 88.1 and $86.8 \%$ during 2003 and 2004, respectively. However, the ratio between observed and expected control efficacy was still within the additive interaction range, with values of 0.91 and 0.93 during 2003 and 2004, respectively.

Time of strobilurin fungicides application. The effect of the timing of strobilurin fungicides application was determined in a 2-year field experiment carried out during 2004 and 2005. During both years of the study, the higher $(P<0.05)$ control efficacy was obtained in plots treated with trifloxystrobin in the two first or two intermediate spray applications, with values ranging from 89.2 to 90.8 and 95 to $96.6 \%$ during 2004 and 2005, respec- tively (Fig. 2). Delaying the trifloxystrobin treatments until the end of the summer by applying them in the last two treatments led in a significantly lower control efficacy $(P<0.05)$ compared with the remaining treatment schedules during 2004; whereas, during 2005 in this treatment schedule, control efficacy was similar $(P>0.05)$ to that observed in plots treated only with trifloxystrobin.

\section{DISCUSSION}

In the area of Thessaly, central Greece, where the experimental fields were established, Cercospora leaf spot is the most important foliar disease of sugar beet. Disease epidemics usually initiate during June and terminate in the middle of September, when cooler temperatures arrest disease development. Disease severity in the experimental fields generally was high

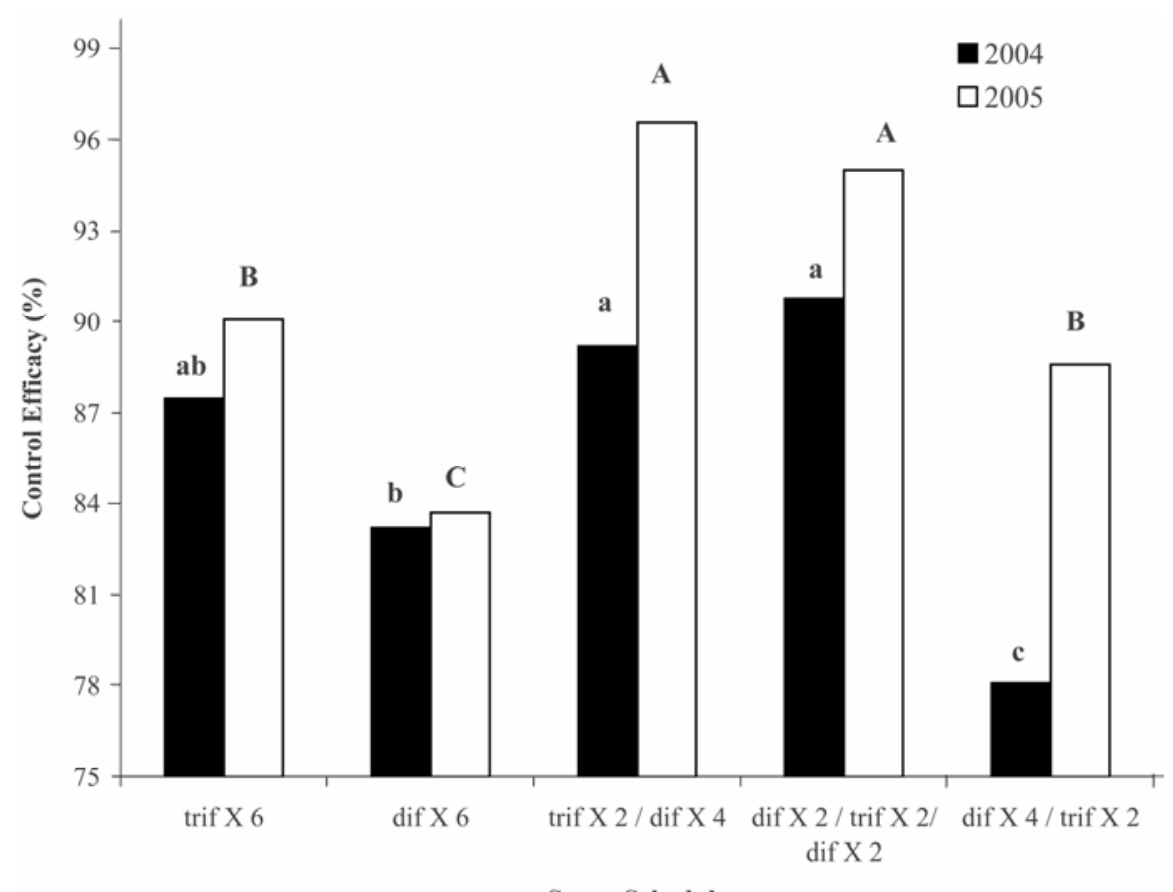

Spray Schedule

Fig. 2. Control efficacy (\%) of Cercospora leaf spot of sugar beet in experimental field plots treated with several application schedules of strobilurin fungicides during 2004 and 2005. The complete fungicide spray schedule is shown in Table 1. Different letters on the columns indicate significant differences according to Fischer's least significant difference test at $P=0.05$. Percentage values were transformed to arcsine $\sqrt{ } \%$ prior the statistical analysis.

Table 3. Area under disease progress curve (AUDPC), observed and expected control efficacy, and sucrose yield in sugar beet experimental field plots treated with several mixtures of strobilurin fungicides during 2003 and $2004^{\mathrm{x}}$

\begin{tabular}{|c|c|c|c|c|c|c|c|c|c|c|c|}
\hline \multirow[b]{4}{*}{ Treatment } & \multirow[b]{4}{*}{ Appl. $^{z}$} & \multicolumn{10}{|c|}{ Year } \\
\hline & & \multicolumn{5}{|c|}{2003} & \multicolumn{5}{|c|}{2004} \\
\hline & & \multirow[b]{2}{*}{ AUDPC } & \multicolumn{3}{|c|}{ Control $(\%)^{\mathrm{y}}$} & \multirow[b]{2}{*}{ Sucrose } & \multirow[b]{2}{*}{ AUDPC } & \multicolumn{3}{|c|}{ Control $(\%)^{y}$} & \multirow[b]{2}{*}{ Sucrose } \\
\hline & & & Obs & Exp & Ratio & & & Obs & $\operatorname{Exp}$ & Ratio & \\
\hline Chlorothalonil & 750 & $1.983 \mathrm{~b}$ & $35.7 \mathrm{i}$ & $\ldots$ & $\ldots$ & $11.37 \mathrm{~cd}$ & $2.017 \mathrm{~b}$ & $32.7 \mathrm{~g}$ & $\ldots$ & $\ldots$ & $8.82 \mathrm{bc}$ \\
\hline Maneb & 2,000 & $1.650 \mathrm{c}$ & $46.5 \mathrm{~h}$ & $\ldots$ & $\ldots$ & $11.57 \mathrm{bcd}$ & $2.013 \mathrm{~b}$ & $32.9 \mathrm{~g}$ & $\ldots$ & $\ldots$ & $9.30 \mathrm{~b}$ \\
\hline Flutriafol & 50 & $1.371 \mathrm{~d}$ & $55.6 \mathrm{~g}$ & $\ldots$ & $\ldots$ & $12.02 \mathrm{abcd}$ & $1.737 \mathrm{c}$ & $42.1 \mathrm{f}$ & $\ldots$ & $\ldots$ & $10.97 \mathrm{ab}$ \\
\hline Difenoconazole & 75 & $952 \mathrm{e}$ & $69.2 \mathrm{f}$ & $\ldots$ & $\ldots$ & $12.60 \mathrm{abc}$ & $1.400 \mathrm{~d}$ & $53.3 \mathrm{e}$ & $\ldots$ & $\ldots$ & $9.86 \mathrm{~b}$ \\
\hline Azoxystrobin & 150 & $1.100 \mathrm{e}$ & $64.3 \mathrm{f}$ & $\ldots$ & $\ldots$ & $12.00 \mathrm{abcd}$ & $1.335 \mathrm{~d}$ & $55.5 \mathrm{e}$ & $\ldots$ & $\ldots$ & $9.62 \mathrm{~b}$ \\
\hline Trifloxystrobin & 150 & $194 \mathrm{ij}$ & $93.8 \mathrm{abc}$ & $\ldots$ & $\ldots$ & $13.25 \mathrm{abc}$ & $318 \mathrm{hi}$ & $89.4 \mathrm{abc}$ & & & $9.46 \mathrm{~b}$ \\
\hline Azoxystrobin/chlorothalonil & $150 / 750$ & $625 \mathrm{f}$ & $79.8 \mathrm{e}$ & 77.1 & 1.03 & $12.80 \mathrm{abc}$ & $692 \mathrm{e}$ & $77.0 \mathrm{~d}$ & 70.1 & 1.09 & $8.67 \mathrm{bc}$ \\
\hline Azoxystrobin/maneb & $150 / 2,000$ & $550 \mathrm{fg}$ & $82.2 \mathrm{de}$ & 81.0 & 1.01 & $13.35 \mathrm{abc}$ & $611 \mathrm{ef}$ & $79.7 \mathrm{~d}$ & 70.2 & 1.13 & $9.76 \mathrm{~b}$ \\
\hline Azoxystrobin/flutriafol & $150 / 50$ & 442 gh & $85.7 \mathrm{de}$ & 84.2 & 1.01 & $13.45 \mathrm{abc}$ & $494 \mathrm{fg}$ & $83.6 \mathrm{~cd}$ & 74.3 & 1.12 & $10.11 \mathrm{ab}$ \\
\hline Azoxystrobin/difenoconazole & $150 / 75$ & $336 \mathrm{hi}$ & $89.1 \mathrm{bcd}$ & 89.1 & 1.00 & $13.67 \mathrm{ab}$ & $402 \mathrm{gh}$ & $86.6 \mathrm{bc}$ & 79.3 & 1.09 & $10.39 a b$ \\
\hline Trifloxystrobin/chlorothalonil & $150 / 750$ & $368 \mathrm{~h}$ & $88.1 \mathrm{~cd}$ & 96.1 & 0.91 & $14.15 \mathrm{a}$ & $397 \mathrm{gh}$ & $86.8 \mathrm{bc}$ & 92.9 & 0.93 & $9.61 \mathrm{~b}$ \\
\hline Trifloxystrobin/maneb & $150 / 2,000$ & $116 \mathrm{j}$ & $96.2 \mathrm{ab}$ & 96.7 & 0.99 & $13.2 \mathrm{abc}$ & $200 \mathrm{ij}$ & $93.4 \mathrm{ab}$ & 92.9 & 1.00 & $10.37 \mathrm{ab}$ \\
\hline Trifloxystrobin/flutriafol & $150 / 50$ & $144 \mathrm{j}$ & $95.3 \mathrm{ab}$ & 97.3 & 0.97 & $14.10 \mathrm{a}$ & $96 \mathrm{j}$ & $96.8 \mathrm{a}$ & 93.9 & 1.03 & $10.64 \mathrm{ab}$ \\
\hline Trifloxystrobin/difenoconazole & $150 / 75$ & $85 \mathrm{j}$ & $97.3 \mathrm{a}$ & 98.1 & 0.99 & $14.2 \mathrm{a}$ & $110 \mathrm{j}$ & $96.4 \mathrm{a}$ & 95.1 & 1.01 & $11.07 \mathrm{a}$ \\
\hline Control & $\ldots$ & $3.081 \mathrm{a}$ & $\ldots$ & $\ldots$ & $\ldots$ & $9.82 \mathrm{~d}$ & $2.997 \mathrm{a}$ & $\ldots$ & $\ldots$ & $\ldots$ & $7.71 \mathrm{c}$ \\
\hline
\end{tabular}

${ }^{x}$ AUDPC values were calculated according to Wolf and Verreet (24); Sucrose $=$ sucrose yield, ton ha $^{-1}$. Means followed by different letters in the column are significantly different according to Fischer's least significant difference test at $P=0.05$.

${ }^{y}$ Percentage control values were calculated as 100 - incidence (treated)/incidence (untreated). Percentage values were transformed to arcsine $\sqrt{ } \%$ for statistical analysis. Obs $=$ observed and Exp $=$ expected; expected control efficacy was calculated according to Gisi (8).

${ }^{\mathrm{z}}$ Appl. $=$ application dose, g a.i. ha ${ }^{-1}$. 
during all 4 years of the study. Cercospora leaf spot was the only major disease observed on sugar beet plants.

All four of the strobilurin fungicides suppressed Cercospora leaf spot significantly compared with untreated plots. However, there were significant differences in efficacy among them. The most effective fungicide was trifloxystrobin, which provided high levels of control efficacy even when applied at the lower application dose tested of $100 \mathrm{~g}$ a.i. ha ${ }^{-1}$, followed by pyraclostrobin, which also provided high levels of control of the disease. Both fungicides were superior to difenoconazole and chlorothalonil at all three application doses. Azoxystrobin provided moderate control efficacy, whereas kresoxim-methyl provided rather poor control of the disease even when applied at the higher application dose tested of $200 \mathrm{~g}$ a.i. ha ${ }^{-1}$. Control of the disease obtained by kresoxim-methyl was similar to the control efficacy obtained by applications of chlorothalonil. Differences in the level of control efficacy against fungal pathogens obtained by the several strobilurin fungicides have been observed previously (5) and can be explained by variation in the level of intrinsic activity of each fungicide against a specific pathogen. Moreover, the biological activity of the fungicides under field conditions is influenced by several parameters, such as the physical or chemical properties of the active ingredient, plant characteristics, environmental conditions, and application technique $(6,25,27)$. In a recent study, pyraclostrobin showed a significantly better performance compared with azoxystrobin against Cercospora leaf spot of sugar beet (16). To the best of our knowledge, the current study is the first one comparing the efficacy of four strobilurin fungicides applied at several application doses against $C$. beticola.

Fungicides mixtures are used to (i) broaden the spectrum of antifungal activity, (ii) exploit synergistic or additive interaction between the fungicide partners, and (iii) reduce the evolution of resistance to fungicide partners within the fungal population (8). Mixtures of both azoxystrobin and trifloxystrobin with the systemic fungicides tested provided a high control efficacy, showing an additive effect between the fungicide mixture partners. However, despite the high control efficacy provided, these mixtures should be used with caution because significant interdependence of isolate sensitivities to strobilurins and DMIs has been observed in other pathogens (27), and this probably also would be the case in $C$. beticola. If this is the case, the use of strobilurin and triazole fungicides in mixtures could lead to acceleration of pathogen resistance to both fungicide classes.

Traditional protective fungicides such as maneb or chlorothalonil are used worldwide for the control of Cercospora leaf spot of sugar beet, providing an adequate control of the disease early in the season when inoculum pressure is low; however, they fail later in the season when inoculum pressure increases (19). However, the use of these fungicides in mixture with azoxystrobin increased the efficacy obtained by the mixture partners when applied alone, providing a satisfactory control of the disease. Similarly, the mixture of maneb with trifloxystrobin provided a high disease control efficacy. In all these combinations, the interaction between the fungicide mixture partners seems to be additive, with the ratio of observed and expected control efficacy ranging around the value of 1 . Interestingly, in the mixtures of trifloxystrobin and chlorothalonil, the ratio of observed and expected control efficacy had values of 0.91 and 0.93 for 2003 and 2004, respectively, which were lower than the respective values of the remaining combinations tested. Such results indicate that a negative interaction between trifloxystrobin and chlorothalonil probably exists. Nevertheless, it would have been interesting to have tested trifloxystrobin in a lower application dose, providing control efficacy less than $70 \%$, to confirm such an interaction. The lower ratios between observed and expected control efficacy for the mixtures of trifloxystrobin and chlorothalonil could be a preliminary indication of negative interaction between these fungicides; consequently, further research is required to confirm whether such an interaction indeed exists. Under the light of the above-mentioned results, it could be concluded that mixtures of strobilurin fungicides with some conventional protective fungicides, such as maneb or chlorothalonil, could be used against the disease, particularly in areas where resistance to DMIs already has been observed. This tactic not only could reduce strobilurin selection pressure by applying them at a reduced rate but also could reduce the number of DMI applications, thus reducing DMI selection pressure while retaining a commercially acceptable disease control efficacy. Moreover, this tactic allows the elimination of DMI-resistant phenotypes because strobilurin fungicides efficiently control these strains, as has been shown by laboratory and field experiments (14).

The third goal of this research was to determine how the high control efficacy of the strobilurin fungicides could best be utilized in spray programs applied for Cercospora leaf spot control, particularly under the light of the Fungicide Resistance Action Committee (FRAC) guidelines suggesting that strobilurin fungicides should not constitute more than 30 to $50 \%$ of the total number of fungicide spray applications made to the crop during one season (5). The reduced number of strobilurin fungicide treatments is a prerequisite for delaying the development of resistance to this fungicide class, which has a qualitative-disruptive pattern $(4,9,20)$. For this purpose, six-treatment spray programs were designed, including applications of trifloxystrobin in the two first treatments, the two intermediate treatments, and the two last treatments; whereas, for the remaining treatments in each spray schedule, the DMI fungicide difenoconazole was used. The results of this study showed that the timing of strobilurin applications plays a crucial role in successful disease management. The control of the disease was significantly higher in plots treated with trifloxystrobin applied in either the first two or the middle two spray applications compared with that in plots treated with trifloxystrobin in the last two spray applications. Such results are in accordance with the hypothesis that the strobilurin fungicides are best applied prior to infection or in the early stages of the disease development (5). It is well established that strobilurin fungicides act as strong inhibitors of the early stages in the infection cycle, including spore germination and penetration $(10,21,26,28)$. Consequently, the strobilurin fungicides provide the maximum of their activity prior to infection or at the early stages of the disease epidemic. Moreover, post-infection applications of strobilurin fungicides increase the risk for resistance development because they may allow the growth of isolates with sensitivity lower than the average and, consequently, accelerate their speed of selection (17).

Currently, control of Cercospora leaf spot of sugar beet in Greece and in many other countries worldwide is based on fungicides that are applied preventively. Applications are initiated before the onset of the disease and continued regularly at 15- to 20-day intervals until the middle of September. In consequence, a large number of fungicide spray applications is required for successful disease management. Incorporation of some of the strobilurin fungicides into the spray programs would be a valuable tool in order to achieve both satisfactory control of the disease and a delay in the evolution of resistance to DMIs. The results presented in this study provide important information related to the efficacy of four strobilurin fungicides at three different application doses and to the efficacy and the interactions of mixtures of strobilurin fungicides and either DMI or protectant fungicides. In addition, data related to the most appropriate time for strobilurin fungicides application are provided that also can be useful for other diseases requiring many spray applications for their control.

\section{LITERATURE CITED}

1. Ammermann, E., Lorenz, G., Schelberger, K., Wenderoth, B., Sauter, H., and Rentzea, C. 1992. BAS $490 \mathrm{~F}$ - a broad spectrum fungicide with a new mode of action. Pages 403-410 in: Proc. BCPC Conf. Pests Dis. BCPC, Farnham, Surrey, UK. 
2. Anesiadis, T., Karaoglanidis, G. S., and Tzavella-Klonari, K. 2003. Protective, curative and eradicant activity of the strobilurin fungicide azoxystrobin against Cercospora beticola and Erysiphe betae. J. Phytopathol. 151:647-651.

3. Anke, T. 1995. The antifungal strobilurins and their possible ecological role. Can. J. Bot. 73(Suppl. 1):940-945.

4. Avila-Adame, C., Olaya, G., and Köller, W. 2003. Characterization of Colletotrichum gramminicola isolates resistant to strobilurinrelated $\mathrm{Q}_{0}$ fungicides. Plant Dis. 87:14261432.

5. Bartlett, D. W., Clough, J. M., Godwin, J. R., Hall, A. A., Hamer, M., and Parr-Dobrzanski, B. 2002. The strobilurin fungicides. Pest Manage. Sci. 58:649-662.

6. Bickers, U., Oerke, E. C., and Dehne, H. D. 1999. Influence of formulation and application on the biological availability and efficacy of systemic fungicides. Pages 131-136 in: Modern Fungicides and Antifungal Compounds. $\mathrm{H}$. Lyr, P. E. Russell, H. W. Hehne, and H. D. Sisler, eds. Intercept Ltd., Andover, UK.

7. Byford, W. J. 1996. A survey of foliar diseases of sugar beet and their control in Europe. Pages 1-10 in: Proc. 59th IIRB Congress.

8. Gisi, U. 1996. Synergistic interaction of fungicides in mixtures. Phytopathology 86:12731279.

9. Gisi, U., Sierotzki, H., Cook, A., and McCaffery, A. 2002. Mechanisms influencing the evolution of resistance to $\mathrm{Q}_{\mathrm{o}}$ inhibitor fungicides. Pest Manage. Sci. 58:859-867.

10. Godwin, J. R., Young, J. E., and Hart, C. A. 1994. ICIA 5504: effects on development of cereal pathogens. Pages 259-264 in: Proc. BCPC Conf. Pests Dis. BCPC, Farnham, Surrey, UK.
11. Horsfall, J. G., and Barrat, R. W. 1945. An improved rating system for measuring plant diseases. (Abstr.) Phytopathology 35:655.

12. Ioannidis, P. M., and Karaoglanidis, G. S. 2000. Resistance of Cercospora beticola Sacc. to fungicides. Adv. Sugar Beet Res. IIRB 2:123-147.

13. Karadimos, D. A., Karaoglanidis, G. S., and Tzavella-Klonari, K. 2005. Biological activity and physical modes of action of the $\mathrm{Q}_{\mathrm{o}}$ inhibitor fungicides trifloxystrobin and pyraclostrobin against Cercospora beticola. Crop Prot. 24:23-29.

14. Karaoglanidis, G. S., and Bardas, G. 2006. Control of benzimidazole- and DMI-resistant strains of Cercospora beticola with strobilurin fungicides. Plant Dis. 90:419-424.

15. Karaoglanidis, G. S., Karadimos, D. A., Ioannidis, P. M., and Ioannidis, P.I. 2003. Sensitivity of Cercospora beticola populations to fentin-acetate, benomyl and flutriafol in Greece. Crop Prot. 22:735-740.

16. Khan, M. F. R., and Smith, L. R. 2005. Evaluating fungicides for controlling Cercospora leaf spot on sugar beet. Crop Prot. 24:79-86.

17. Köller, W., Parker, D. M., Turechek, W.W., Avila-Adame, C., and Cronshaw, K. 2004. A two-phase resistance response of Venturia inaequalis populations to the $\mathrm{Q}_{\mathrm{O}} \mathrm{I}$ fungicides kresoxim-methyl and trifloxystrobin. Plant Dis. 88:537-544.

18. Margot, P., Huggenberger, F., Amrein, J., and Weiss, B. 1998. CGA 279202: a new broad spectrum strobilurin fungicide. Pages 375-382 in: Proc. BCPC Conf. Pests Dis. BCPC, Farnham, Surrey, UK.

19. Meriggi, P., Rosso, F., Ioannidis, P. M., and Ayala Garcia, J. 2000. Fungicide treatments against Cercospora leaf spot in sugar beet (Beta vulgaris L.). Adv. Sugar Beet Res.
IIRB 2:77-102.

20. Olaya, G., and Köller, W. 1999. Diversity of kresoxim-methyl sensitivities in baseline populations of Venturia inaequalis. Pestic. Sci. 55:1083-1088.

21. Reuveni, M., and Sheglov, D. 2002. Effects of azoxystrobin, difenoconazole, polyoxin B (polar) and trifloxystrobin on germination and growth of Alternaria alternata and decay in red delicious apple fruit. Crop Prot. 21:951955.

22. Shane, W. W., and Teng, P.S. 1992. Impact of Cercospora leaf spot on root weight, sugar yield and purity of Beta vulgaris. Plant Dis. 76:812-820.

23. Weiland, J., and Koch, G. 2004. Sugar beet leaf spot disease (Cercospora beticola Sacc.). Mol. Plant Pathol. 5:157-166.

24. Wolf, P. F. J., and Verreet, J. A. 2002. The IPM sugar beet model-an integrated pest management system in Germany for the control of fungal leaf diseases in sugar beet. Plant Dis. 86:336-344.

25. Wong, F. P., and Wilcox, W. F. 2000. Distribution of baseline sensitivities to azoxystrobin among isolates of Plasmopara viticola. Plant Dis. 84:275-281.

26. Wong, F. P., and Wilcox, W. F. 2001. Comparative physical modes of action of azoxystrobin mancozeb and metalaxyl against Plasmopara viticola. Plant Dis. 85:649-656.

27. Wong, F. P., and Wilcox, W. F. 2002. Sensitivity to azoxystrobin among isolates of Uncinula necator: baseline distribution and relationship to myclobutanil sensitivity. Plant Dis. 86:394 404.

28. Ypema, H. L., and Gold, R. E. 1999 Kresoxim-methyl: modification of a naturally occurring compound to produce a new fungicide. Plant Dis. 83:4-19. 